\section{The Expected Federal Budget Surplus: How Much Confidence Should the Public and Policymakers Place in the Projections?}

\author{
Kevin L. Kliesen and Daniel L. Thornton
}

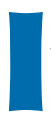
n 1998, the federal government recorded its first budget surplus in more than 25 years. Now, after an extended period of deficits and three consecutive years of surpluses, both the White House Office of Management and Budget (OMB) and the Congressional Budget Office (CBO) have projected annual budget surpluses for at least the next decade. The turnaround in the outlook for the U.S. government's finances is stunning. Under current policies, budget projections show that publicly held government debt, which is currently a little more than $\$ 3.5$ trillion, will be eliminated by around 2010-perhaps earlier if the economy continues to grow faster than anticipated. ${ }^{1}$ The political response to these projections has been rapid. Despite legislated budgetary "caps," fiscal policymakers have already increased spending and reduced taxes relative to previous agreements.

Projected large government surpluses have implications for the current political debate-possibly even the future implementation of monetary policy. ${ }^{2}$ The purpose of this article is to assess the likelihood that the projected surpluses will materialize by comparing previous budget projections with actual outcomes. No one can say for sure whether these projected surpluses will materialize or whether publicly held government debt will be eliminated. If past experience is any guide, however, it seems likely that the market in default risk-free government debt will be with us for some time. Policymakers, accordingly, might be wise to consider this fact before deciding to ramp up spending or cut taxes solely on the basis of current projections.

The first section of the paper reviews the current budget projections of the $\mathrm{CBO}$ and the $\mathrm{OMB}$; it also

Kevin L. Kliesen is an economist and Daniel L. Thornton is a vice president and economist at the Federal Reserve Bank of St. Louis. Stephen Majesky and Thomas A. Pollmann provided research assistance. reviews government budget accounting practices and discusses whether government debt is rising or falling. As a means of ascertaining the probability that the current projected surpluses will materialize, the second section analyzes the CBO's projections since 1976 relative to actual outcomes. The third section of the paper analyzes the major sources of error in these projections. The conclusions are presented in the fourth section.

\section{CURRENT BUDGET PROJECTIONS}

Table 1 presents the 10-year budget projections and major economic assumptions published by the $\mathrm{CBO}$ and the $\mathrm{OMB}$ in 2000 . The projection period is fiscal years 2001 to 2010 . There are two sets of projections because each agency publishes a major report early in the year and then during the summer. One other fact worth noting is the approach taken by each agency. Generally speaking, $\mathrm{CBO}$ baseline budget projections follow the current services approach, which assumes that the current spending and tax programs remain in place throughout the projection period-though the $\mathrm{CBO}$, at least in recent years, has typically published alternative projections using different spending assumptions. The OMB also publishes a current services (baseline) projection, as well as a projection that traces out the path of the surplus or deficit over time assuming that the Administration's specific policy proposals are enacted. We label the former OMB and the latter OMB*.

According to the January 2000 budget projections shown in Table 1, the CBO projected that the unified budget surplus (the sum of "on budget" and "off budget" revenues and expenses) will rise from $\$ 177$ billion in fiscal year 2001 to just under $\$ 489$ billion by fiscal year 2010. ${ }^{3}$ Cumulatively, the 10-

\footnotetext{
Authors' note: This article was prepared prior to the publication of the projections for FY 2002-10 by the CBO and OMB. See Appendix.

2 The prospect of eliminating publicly held federal debt poses a potential problem for the Fed. Historically, the Fed has implemented monetary policy by buying and selling government securities (open market operations). Because the public's demand for money tends to rise with nominal GDP, over time, the Fed buys more government securities than it sells to increase the supply of money. If the public debt were eliminated, the Fed would be unable to acquire additional government debt. Moreover, it would have to replace its holdings of government debt with something else. The question is what?

3 Off-budget includes Social Security and the U.S. Post Office. Onbudget is everything else-including other trust funds. This baseline-one of three published by $\mathrm{CBO}$ - assumes that discretionary spending grows at the rate of inflation after FY 2000. Because this projection assumes considerably greater discretionary spending levels, it produces the smallest cumulative surplus over the forecast horizon. Specifically, it presumes that the discretionary budget caps that are set to expire in 2002 will not be adhered to. Most budget analysts use this baseline projection.
} 
Table 1

OMB/CBO Unified Surplus Baseline Projections and Economic Assumptions

\begin{tabular}{|c|c|c|c|c|c|c|}
\hline & \multicolumn{3}{|c|}{ Surplus/deficit projections (billions of dollars) } & \multicolumn{3}{|c|}{ Economic assumptions (fiscal year) } \\
\hline & 2001 & 2010 & Cumulative & Real GDP & Inflation & 10-Year bond \\
\hline CBO (January 2000) & 177 & 489 & 3,152 & 2.77 & 2.49 & 5.84 \\
\hline CBO (July 2000) & 268 & 685 & 4,561 & 2.79 & 2.60 & 5.90 \\
\hline OMB* (February 2000) & 184 & 363 & 2,519 & 2.71 & 2.59 & 6.10 \\
\hline OMB & 171 & 457 & 2,919 & 2.71 & 2.59 & 6.10 \\
\hline OMB* (June 2000) & 228 & 416 & 2,912 & 2.93 & 2.60 & 6.30 \\
\hline OMB & 239 & 670 & 4,193 & 2.93 & 2.60 & 6.30 \\
\hline
\end{tabular}

NOTE: Growth of real GDP, inflation, and the 10-year U.S. Treasury bond rate are averages of annual forecasts/projections. CBO and $\mathrm{OMB}$ projections use the CPI inflation rate. OMB is the Administration's current services projection.

\section{Figure 1}

\section{The Federal Surplus/Deficit as a Percentage of GNP}

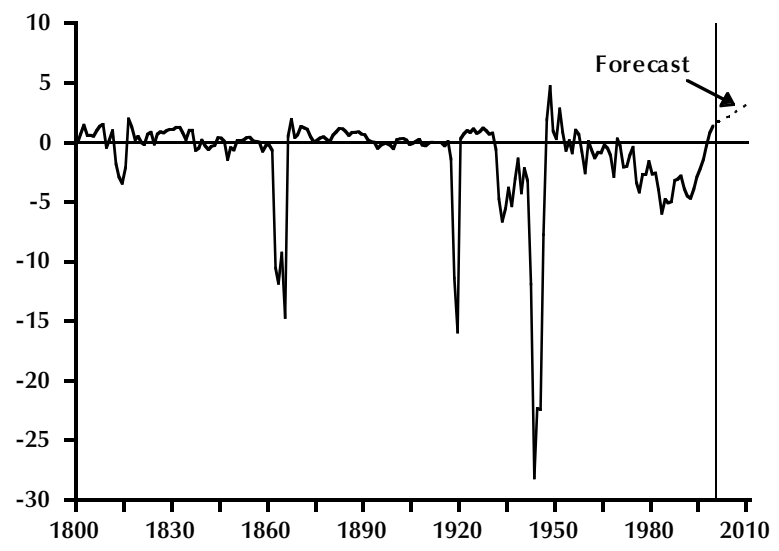

SOURCE: International Historical Statistics: The Americas 1750-1993; and Congressional Budget Office (2000).

year unified budget surplus was expected to sum to just under $\$ 3.2$ trillion. Although the Administration expected a somewhat smaller cumulative surplus because of the President's budget proposals, roughly $\$ 2.5$ trillion $\left(\mathrm{OMB}^{*}\right)$, its cumulative current services projection (OMB) was fairly close to the CBO's.

These projections are not only large in dollar terms, but, if realized, would be historically large as a percentage of gross domestic product (GDP). Figure 1 shows the U.S. annual surplus/deficit as a percent of GNP/GDP since 1800 and the projections to 2010 .

There is no prior multiyear period when the actual surplus was as persistently large as the CBO's current projections. Prior to 1970 the only multiyear periods of protracted deficits were associated with wars.
Since these projections were made, the U.S. fiscal outlook has improved even further according to the mid-year updates. As seen in Table 1, the CBO and OMB have increased substantially their cumulative 10-year budget surplus projections. The CBO's Budget and Economic Update released in July 2000 projects a cumulative $\$ 4.6$ trillion surplus. In updated projections published in its Mid-Session Review released in late June 2000 , the Administration's projected 10-year surplus $\left(\mathrm{OMB}^{*}\right)$ was increased from $\$ 2.5$ trillion to $\$ 2.9$ trillion. The biggest surprise was the Administration's sharply higher projection of the 10-year current services surplus. Using slightly more optimistic economic assumptions, the OMB later estimated that the unified budget surplus will total $\$ 4.2$ trillion over the 2001-10 period, which is more than 40 percent, or $\$ 1.3$ trillion, greater than the February 2000 current services baseline. Revised economic assumptions account for $\$ 984$ billion, or more than 75 percent, of this $\$ 1.3$ trillion upward revision. ${ }^{4}$

\section{Basic Budget Accounting: Is the Govern- ment Debt Rising or Falling?}

One can think of the government debt as being the sum of all surpluses and deficits during U.S. history. In the very long run this is approximately true. In any given year, however, when the government

\footnotetext{
4 Specifically, real GDP growth averages about one quarter of a percentage point more a year. Technical reestimates account for another $\$ 375$ billion of the total upward revision, roughly split equally between increased receipts and lower expenditures. See OMB (2000) Tables 5, 8, and 9. Finally, legislation enacted since February 2000 is expected to decrease the projected surplus by $\$ 84$ billion over this 10-year horizon.
} 


\section{Table 2}

\section{Government Accounting with Trust Fund Surpluses (Billions of Dollars)}

Fiscal year $1998 \quad$ Fiscal year $1999 \quad$ Change 1998-99

Debt outstanding

Total government securities

Less:

Securities held by government accounts

Equals:

Government securities held by the public

Sources of financing

Unified surplus, FY 1999

Borrowing from the public

Operating cash, change

Other

\section{Surplus/deficit (-)}

Federal funds

Trust funds

Total unified surplus/deficit

\section{Memorandum}

Treasury cash balance, end of FY 1999
$5,478.7$

$1,757.1$

$3,721.6$

$3,632.9$

216.1

$-88.7^{*}$

124.4

$-88.7^{*}$

$-17.6$

$-18.2$

$$
\begin{array}{r}
-92.0 \\
161.2 \\
69.2
\end{array}
$$

-88.3
212.7
124.4

NOTE: Includes debt issued by government agencies. Value of debt outstanding is the face value less the net unamortized premium and discount, otherwise known as the accrual amount. Totals may not sum because of rounding. *Identical values calculated by two separate methods.

SOURCE: Office of Management and Budget, Historical Tables, Tables 1.4 and 7.1; Federal Reserve Board of Governors, Federal Reserve Bulletin, November 2000, Table 1.38.

runs a deficit, it can borrow from the public or change its holdings of cash or other assets. ${ }^{5}$ Conversely, when the government runs a surplus, it can retire its debt or increase its holdings of cash or other assets. Consequently, over any given period, government debt will not necessarily change dollarfor-dollar with the surplus or deficit.

To further complicate matters, whether the debt changes or not depends on where in the government the surplus or deficit is generated. Within the government there are a number of trust funds, the best known of which is the federal Old-Age and Survivors Disability Insurance (OASDI) trust fundSocial Security. When a surplus is generated within the trust fund, the government issues nonmarketable interest-bearing debt to the trust fund. This is essentially an IOU that one area of government issues to another. Likewise, when a trust fund runs a deficit, the government must buy back the nonmarketable debt using surpluses from elsewhere (should they exist), borrow from the public, or raise taxes. ${ }^{6}$

In the government accounts, revenues and expenditures are thus classified as either federal funds or trust funds. Trust fund revenues are earmarked for a specific program or purpose, such as OASDI or federal road, bridge, and highway construction (highway trust fund). If the government runs a surplus in both its federal and trust funds accounts, total debt will fall. ${ }^{7}$ If the government runs a surplus in only one of its accounts, total debt need not fall. For example, in fiscal year (FY) 1999 the federal government's $\$ 124.4$ billion budget surplus was the result of a $\$ 88.3$ billion deficit in the federal

\footnotetext{
5 The other assets include such things as special drawing rights (SDRs), allocations of SDRs, the reserve position in the International Monetary Fund (IMF), loans to the IMF, changes in the gold stock, etc. See Rasche (1980) for more details.

6 The accounting is more complicated because the interest income from the nonmarketable debt issued to trusts is accumulated in a separate account. Consequently, the government does not have to buy back the debt issued to the trusts until the accumulated interest income in these accounts is exhausted. This interest "income," however, is a mere intragovernment bookkeeping entry, since it cannot be used to offset expenditures elsewhere. In other words, because budget accounts measure transactions with the public, even though the trust funds may credit the government with interest income from nonmarketable debt, the reported unified budget is unaffected.

7 This is the general case. It is also possible to accumulate other assets with the surplus or decide to hold increased cash balances.
} 


\section{Figure 2}

\section{Gross Federal Debt and Federal Debt Held by the Public}

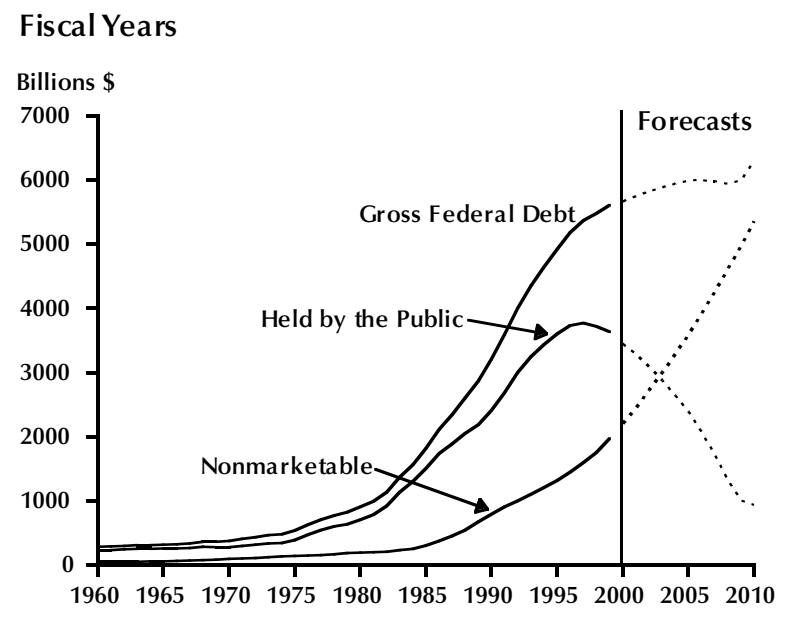

SOURCE: Congressional Budget Office (2000)

funds account - mostly individual and corporate income tax revenues used to fund, for example, defense outlays or international aid programs - and a $\$ 212.7$ billion surplus in the trust funds account. ${ }^{8}$ As detailed in Table 2 , the net government surplus was thus $\$ 124$ billion, of which nearly $\$ 89$ billion was used to retire government debt held by the public. Hence, publicly held government debt fell while total government debt rose.

Figure 2 shows the evolution of total (gross) federal debt, publicly held government debt, and nonmarketable debt since 1960, along with the CBO's projections through 2010. Despite cumulative budget surpluses of nearly $\$ 200$ billion in fiscal years 1998 and 1999, gross federal indebtedness rose by nearly $\$ 130$ billion. The reason, of course, is that the government issued nonmarketable debt to trust funds equal to their surpluses during this period. The largest of these is the OASDI fund, which "held" \$855 billion in government debt at the end of FY 1999. Another $\$ 1.15$ trillion was held by other trust funds, such as the federal employees' retirement fund ( $\$ 474.7$ billion) and the hospital insurance portion of Medicare ( $\$ 153.8$ billion).

The practice of issuing nonmarketable debt to trust funds was motivated by a desire to assure the public that the benefits that have been promised under specific programs will be forthcoming. Unlike private sector accounting rules, which mandate that firms fund their pension-plan benefits on an accrual basis, the federal government is not required to hold sufficient assets to compensate future beneficiaries their accrued benefits. The reason, of course, is that the government can, if necessary, raise taxes by the amount necessary to pay existing retirees-tax future workers to pay today's workers' retirement benefits. Alternatively, the government could borrow from the public when Social Security program payments exceeded payroll tax revenues, as it did frequently prior to $1983 .{ }^{9}$

Given that there was no explicit commitment to either raise taxes or borrow from the public, however, some feared that the government might instead renege on its commitment to Social Security recipients by reducing program benefits when the OASDI program began to run persistent deficits. Consequently, Congress attempted to tie its own hands by issuing nonmarketable, interest-bearing debt to the Social Security Administration in the amount of the Social Security surplus - the so-called Social Security "Lock Box."

\section{The "Gray" Area of Future Budgets}

Although publicly held debt is currently declining and may decline further, it is unlikely that public debt will stay at zero very long, should it ever get there. The reason is demographics. Recent generational accounting by Gokhale et al. (2000) suggests that the net tax liabilities of future generations will increase significantly because of the pending retirement of the baby boom generation. Likewise, according to the 2000 Social Security Trustees Annual Report, program expenses are projected to exceed payroll tax revenue beginning in 2016.

The federal government's unfunded liability of the Social Security program measured on an accrual basis was about $\$ 10.4$ trillion in 1999 according to congressional testimony by CBO Director Dan Crippen. This is more than 12 times larger than the $\$ 855$ billion in nonmarketable debt held by the OASDI trust fund in FY 1999. Consequently, it seems unlikely that the government will be able to meet its future obligations without borrowing from the public. In other words, at some point, publicly held debt

8 This accounting is a little misleading because the surpluses in some trusts are due to intragovernmental transfers from the general funds to these trust funds. Much of these transfers are the direct consequence of the trust funds holding interest-bearing government debt. See CBO (2000a, pp. 22-23) for additional details.

9 Since the 1983 Social Security reforms (Greenspan Commission), payroll tax revenues collected by the government to finance OASDI benefits have exceeded program payments to recipients by a little more than $\$ 50$ billion a year, while the surplus for all federal trust funds averaged a little more than $\$ 100$ billion a year. 
will inexorably rise.

Indeed, projections published in the CBO's latest Long-Term Budget Outlook indicate such a scenario: Even if Congress and the Administration manage to wall off all of the projected (cumulative) \$2.4 trillion off-budget surplus during the next decade in a "lock box," the debt held by the public will rise to a little more than 62 percent of GDP by 2040, compared with about 40 percent in 1999. Further simulations project that the share of the debt held by the public would rise to 184 percent of GDP by 2040 if there were no annual surpluses during the next 10 years. Accordingly, unless there is a surplus elsewhere in government to offset the Social Security deficit, the government will have to make up the shortfall by raising taxes, reducing benefits, and/or issuing marketable debt. ${ }^{10}$ If the last option is used, publicly held debt will rise as the trust funds' holdings of debt decline.

\section{PAST PROJECTIONS AND ACTUAL EXPERIENCE}

Will publicly held government debt go to zero? Not if the current projected surpluses don't materialize. ${ }^{11}$ Given the relative magnitude of the current surplus projections and the speed with which earlier CBO projections shifted from deficit to surplus, perhaps it is not surprising that nearly 60 percent of the respondents in a recent survey of business economists (conducted by the National Association for Business Economics) indicated that the CBO's budget projections are too optimistic. Only 31 percent of the respondents believed that the projections were reasonable. ${ }^{12}$ It is not just economists who are skeptical of official budget projections. A survey by the Business Council suggests similar skepticism among chief executive officers of major U.S. corporations. ${ }^{13}$

Some insight into the accuracy of budget projections can be obtained by evaluating the CBO's past projections. We focus on the CBO's projections because the $\mathrm{CBO}$ is viewed as an impartial arbiter of the federal government's fiscal outlook. The budget projection process was not intended as a forecasting exercise. It was created to provide a method of analyzing alternative budget proposals. Nevertheless, the public and policymakers frequently treat these projections as forecasts, suggesting —or implementingchanges in spending or taxes based on them.

It is important to note, however, that this exercise is biased against the CBO for a couple of reasons. First, many of the rules employed to calculate the baseline budget projection are set by statute. Consequently, the $\mathrm{CBO}$ is forced to construct its baseline projections under these assumptions, regardless of whether $\mathrm{CBO}$ believes they are realistic. For example, the Deficit Control Act of 1985 mandates that the $\mathrm{CBO}$ project the future discretionary spending levels from current-year appropriations, whether the current-year appropriations are unusually high or low due to special appropriations (e.g., Desert Storm).

The second reason, which is related to the first, stems from the difference between budget projections and forecasts. Baseline budget projections are based on the current services approach, that is, the assumption that the government will leave its current tax and spending programs in place. ${ }^{14}$ This is highly unlikely, so budget projections are almost assuredly going to be wrong. For example, the Omnibus Budget Reconciliation Act (OBRA) of 1993, which sought to produce markedly lower future deficits in relation to earlier projected deficits, produced budget projections markedly different from those of the previous baseline. As described later, the $\mathrm{CBO}$ estimates that about one third of its projection error is legislative, i.e., due to changes in tax and spending programs that were assumed to be constant for the purpose of making the projections. Despite the difficult nature of projecting future fiscal outcomes, it is nonetheless instructive to analyze the CBO's past budget projections.

The CBO began publishing five-year budget projections in January 1976 for FY 1977-81. Figures 3 through 5 present the actual one-year, five-year, and cumulative five-year projected surplus/deficit annually for the period 1976-99. If the CBO's past projections coincided with what subsequently transpired - that is, a zero projection error - then all of the points would lie on the 45-degree line. While few observations fall on the 45-degree line, at the one-

\footnotetext{
${ }^{10}$ Social Security actuaries estimate that the Trust Fund will exhaust its holdings of nonmarketable government debt by about 2037. The extended period reflects the interest "income" that is annually credited to the trust fund. See footnote 7 .

11 See Auerbach (2000) and the other papers published by the Federal Reserve Bank of New York (2000) for discussion of this and other issues.

12 See National Association for Business Economics (2000).

13 See Weill (2000).

14 In making their current services projections, the $\mathrm{CBO}$ and $\mathrm{OMB}$ each assume a path for several key economic variables and then calculate the path of outlays and receipts under the assumption that tax rates and spending programs will not change over the projection period. Tax rates and spending programs - other than automatic stabilizers such as income support programs for the unemployed-do not vary with forecasts of the economy, nor does a policy change endogenously alter the path of the key economic variables. As discussed by Rasche (1985), this is different from a model-based forecast, such as those used by most forecasters.
} 


\section{Figure 3}

\section{Actual and Projected Budget Deficit/Surplus at One-Year Horizon}

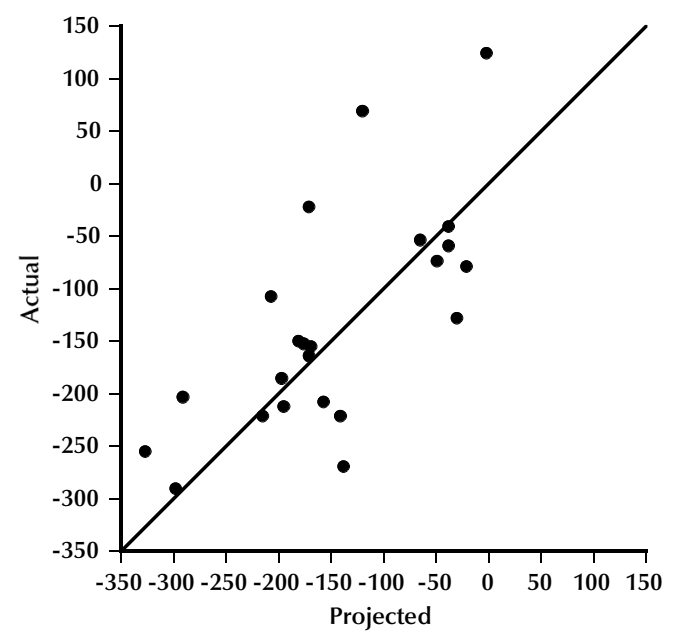

\section{Figure 4}

\section{Actual and Projected Budget Deficit/Surplus at Five-Year Horizon}

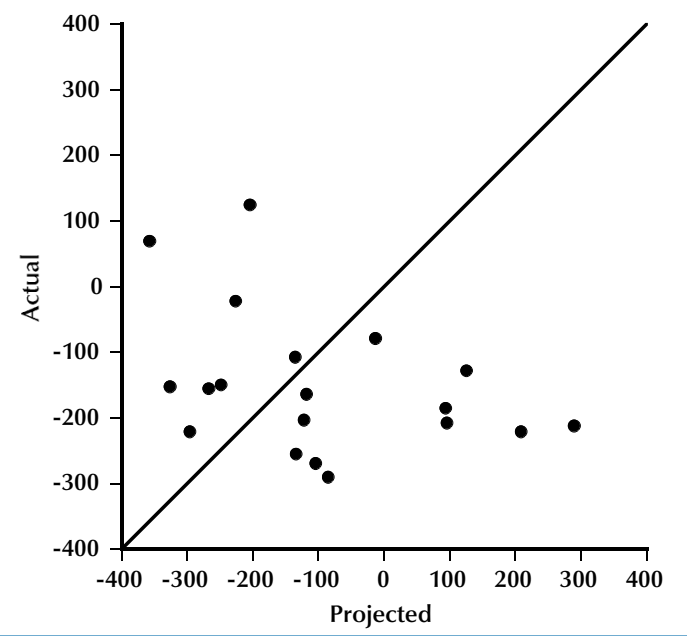

year horizon they are about equally spaced above and below the line, suggesting that the projections are approximately accurate on average. In other words, at the one-year horizon, the average projection error is not too far from zero. More important, at the one-year horizon there is a positive relationship between the projections and the actual outcome. Hence, if the CBO projected that the surplus would increase the next year, there was a tendency for the actual surplus to increase.

At the five-year horizon, outcomes are quite dif-

\section{Figure 5}

Actual and Projected Budget Deficit/Surplus: Cumulative Five-Year

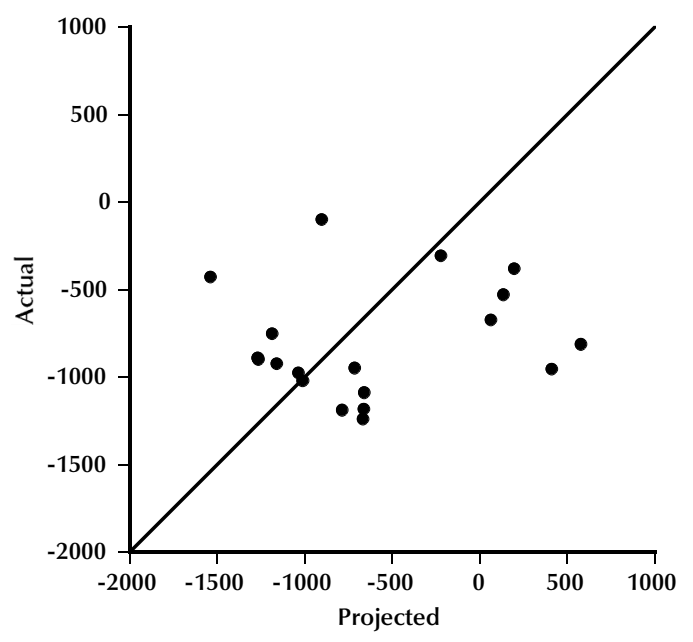

ferent. Figure 4 reveals that there is no relationship between the CBO's projections and the actual surplus/deficit. Not only do none of the observations fall on the 45-degree line, but a large deficit was as likely to occur when the $\mathrm{CBO}$ projected a surplus as it was when the $\mathrm{CBO}$ projected a deficit. At the fiveyear horizon, the CBO's projections have not been a useful indicator of what the future is likely to entail.

The CBO's cumulative five-year projections are more important for the question of whether publicly held government debt will be eliminated. Figure 5 shows that the CBO's cumulative projections have frequently missed their mark. In some cases, the projection errors are very large. For example, in 1980 the CBO projected a $\$ 578$ billion cumulative surplus over the next five years. The actual outcome, however, was a deficit of a little more than $\$ 800$ billion. If past experience is a guide to the future, the CBO's current projection of a cumulative surplus of a little more than $\$ 4.5$ trillion dollars should not be treated as a forecast that can be relied on. The government is as likely to experience a deficit as it is to experience a surplus.

The general impression obtained from Figures 3 through 5 is summarized numerically in Table 3 , which presents summary statistics for the CBO's projection errors (projected less actual) at the one-year and five-year horizons for the surplus/deficit, outlays, and receipts. To make the comparisons more useful, the projection errors are presented as a percentage of nominal GDP. At the one-year horizon, the mean absolute error (MAE) is about 1 percent of GDP. The 


\section{Table 3} CBO Projection Error Statistics: Deficit/Surplus, Total Outlays, and Total Receipts
(Percent of GDP)

\begin{tabular}{|c|c|c|c|c|c|}
\hline Series & $\begin{array}{c}\text { Average } \\
\text { error }\end{array}$ & MAE & $\begin{array}{l}\text { RMS } \\
\text { error }\end{array}$ & Minimum & Maximum \\
\hline \multicolumn{6}{|c|}{ One-year-ahead projection errors } \\
\hline Deficit/surplus & 0.05 & 1.05 & 1.31 & -2.19 & 3.03 \\
\hline Total receipts & 0.03 & 0.75 & 0.99 & -1.79 & 2.83 \\
\hline Individual income taxes & -0.08 & 0.49 & 0.63 & -1.40 & 1.30 \\
\hline Corporate taxes & 0.10 & 0.22 & 0.28 & -0.37 & 0.64 \\
\hline Social insurance taxes & 0.00 & 0.26 & 0.46 & -1.93 & 0.52 \\
\hline Total outlays & 0.25 & 0.56 & 0.69 & -0.83 & 1.46 \\
\hline Mandatory & 0.09 & 0.55 & 0.67 & -1.32 & 1.27 \\
\hline Discretionary & 0.07 & 0.17 & 0.20 & -0.15 & 0.41 \\
\hline \multicolumn{6}{|c|}{ Five-year-ahead projection errors } \\
\hline Deficit/surplus & 1.97 & 4.10 & 5.28 & -4.94 & 12.13 \\
\hline Total receipts & 1.55 & 2.41 & 3.35 & -2.78 & 8.86 \\
\hline Individual income taxes & 1.16 & 1.65 & 2.28 & -1.93 & 6.11 \\
\hline Corporate taxes & 0.35 & 0.71 & 0.91 & -0.79 & 2.00 \\
\hline Social insurance taxes & 0.21 & 0.57 & 0.68 & -1.60 & 1.13 \\
\hline Total outlays & -0.43 & 2.22 & 2.74 & -6.31 & 3.67 \\
\hline Mandatory & -0.09 & 0.70 & 0.84 & -1.66 & 1.30 \\
\hline Discretionary & 0.81 & 0.83 & 1.13 & -0.12 & 2.37 \\
\hline
\end{tabular}

root-mean-squared error (RMSE) is slightly larger at 1.3 percent of GDP, and the range is about 5.2 percent of GDP.

How large are these numbers? One way to put these numbers into perspective is to note that the average deficit during the 1976-99 period was 3.0 percent of GDP. Hence, at the one-year horizon, the MAE is about one third of the average deficit. Moreover, actual surpluses and deficits ranged from -6.0 percent of GDP to 1.4 percent of GDP, so the range of projection errors was about 70 percent of the range of actual surpluses/deficits over the period (5.2 percent/7.4 percent, respectively). Hence, even at the one-year horizon, the projection errors are relatively large.

At the five-year horizon, the MAE is more than 4 percent of GDP and the RMSE is nearly 5.3 percent of GDP. As measured by the RMSE, the projection errors are nearly twice the actual average deficit over the period. This means that the probability is high that the error in the five-year projection would be larger than the largest single-year deficit as a percent of GDP, 6.0 percent. Furthermore, the range of projection errors is over 17 percent of GDP. This is more than double the range of the actual surplus/deficit as a percent of GDP during the 1976-99 period.

Table 3 also shows that the CBO's projections of future revenues are somewhat less accurate than its projections of outlays. Perhaps this is not surprising given the sensitivity of tax revenues to economic conditions. At the one-year horizon, the RMSE for total receipts is nearly 1.0 percent of GDP and is nearly 45 percent larger than the RMSE for total outlays. Not surprisingly, the projection errors by source are much larger at the five-year horizon. Nevertheless, it remains the case that receipts appear to be more difficult to project than outlays. The relative ability to project receipts and outlays appears to equalize somewhat as the projection horizon lengthens.

Table 3 also decomposes receipts and outlays by their major categories. ${ }^{15}$ Individual income tax receipts are the most difficult component of receipts to project at both horizons. In terms of total outlays, discretionary spending projection errors are the smallest at the one-year horizon but are the largest at the five-year horizon. ${ }^{16}$

The reader is once again cautioned that these results should not be taken as criticism of the $\mathrm{CBO}$ per se. It is very doubtful that any other organization or government agency could do significantly better. Rather, these results point out how inherently difficult it is to project the future, especially given

\footnotetext{
${ }^{15}$ Caution must be used with respect to the components of total outlays because we only have a consistent breakdown of total outlays into mandatory and discretionary outlays back to FY 1983 .

${ }^{16}$ See Auerbach (1999) for an analysis of $\mathrm{CBO}$ and OMB revenue forecasts.
} 
that the no-change assumption with respect to tax and spending programs will eventually be violated. ${ }^{17}$

\section{Are the CBO's Projections Biased?}

The data in Table 3 show that the CBO's projections are unbiased at the one-year horizon. The average projection error is 0.05 percent of GDP, and it not significantly different from zero at the 5 percent significance level. At the five-year horizon, however, the average projection error is very large-nearly 2 percent of GDP. Moreover, the average error is significantly larger than zero at the 5 percent level. The average error is about half of the range in the actual surpluses and deficits: 1.4 percent to -6 percent of GDP. Because the $\mathrm{CBO}$ is projecting a surplus through 2005 that is equal to about 3.25 percent of GDP, making a correction for the average bias suggests a bias-corrected projected surplus that is only 1.25 percent of GDP.

\section{THE SOURCES OF PROJECTION ERRORS}

What accounts for the inaccuracies in the CBO's projections and why are they biased? Some insight into the answer to these questions can be obtained by looking at the possible sources of projection errors. Projection errors are typically classified into three types. The first is called legislative errors. As mentioned previously, budget projections are made under the assumption that current government program levels and the current tax structure will remain unchanged over the projection period. This assumption will almost certainly be false, especially at the five-year horizon. It is virtually certain that there will be legislative changes.

For example, the $\mathrm{CBO}$ estimated that the FY 2000 budget passed by Congress and signed into law by the President will reduce the estimated surplus by about $\$ 127$ billion over the 2000-09 horizon. Much of this additional spending has been classified as "emergency" legislation. The combined "emergency" appropriations for FY 1999-2000 totaled $\$ 65.5$ billion, roughly 60 percent of the previous eight years combined. But unlike the appropriations for Desert Storm, the 1993 Great Flood, Hurricane Andrew, and the 1994 Northridge (Los Angeles) earthquake, which were largely passed through traditional supplemental legislation, the bulk of the emergency appropriations in the FY 1999-2000 budgets were regular rather than supplemental. According to the CBO, regular appropriations classified as emergency spending have totaled $\$ 58.6$ billion since 1990 , with nearly 90 percent of that spending occurring in FY 1999-2000. ${ }^{18}$ By contrast, supplemental emergency appropriations totaled just $\$ 14.7$ billion in FY 1999-2000. In effect, then, Congress and the Administration have circumvented the discretionary budget caps that were put into place during the 1990 Budget Enforcement Act by increasingly classifying appropriations as emergency spending. Because the $\mathrm{CBO}$ could not have predicted this outcome, it should not be held responsible for projections that miss the mark because of budgetary chicanery. But this is exactly the point. In other words, although the budget projection process is to some extent biased against the $\mathrm{CBO}$ and thus potentially leads to large subsequent projection errors, legislative errors will occur because neither the $\mathrm{CBO}$ nor anyone else is able to predict how much of the public's money Congress and the Administration will choose to spend.

It is possible that policymakers create legislative errors by responding to budget projections. For example, policymakers could enact changes in tax rates and/or spending from current baseline levels in response to projections of a surplus or deficit. This is not far fetched: Policymakers are debating whether and by how much to increase government spending and/or reduce taxes in anticipation of the historically large projected surpluses. ${ }^{19}$

Furthermore, the interaction of the legislative changes and budget projections can bias the CBO's projections. For example, assume that policymakers, facing a projected surplus, decide to increase spending and/or reduce taxes. The result will be a smaller actual surplus than anticipated (or perhaps a deficit). As a consequence, the projection error (projection less actual) would be positive, i.e., the projections will be biased upward. On the other hand, if policymakers responded to projections of a deficit by reducing spending, raising taxes, or both, the average projection error would be negative.

\footnotetext{
17 The CBO (2000a, p. 97) readily acknowledges "considerable uncertainty" in making its multiyear budget projections.

18 These appropriations exclude spending associated with Desert Storm/Desert Shield operations.

${ }^{19}$ For example, the House of Representatives has voted to repeal the estate tax and the marriage penalty. In addition, the Congress passed, and the President signed, legislation repealing the earnings tax for senior citizens. On the spending side, there is considerable discussion of creating a new Medicare entitlement program to pay for prescription drugs for the elderly.
} 
Does such behavior account for the positive average projection error in the CBO's projections at the five-year horizon? It seems unlikely: During most of the period, the $\mathrm{CBO}$ was projecting a deficit such that the bias created by the interaction of budget projections and legislative changes should have created a negative bias. Figure 5 shows, however, that there were five years (1977-81) when the CBO was projecting a surplus at the five-year horizon. The actual experience was that the government ran a deficit. Moreover, it is clear from Figure 5 that these observations account for the positive bias reported in Table 3 at the five-year horizon. Hence, it is possible that the bias occurred because the government increased spending or reduced taxes in response to projections of a budget surplus five years out. Another and perhaps more likely explanation is that, like most forecasters at the time, the CBO failed to forecast the rapid run-up in oil prices, the subsequent acceleration in inflation, and the recessions in 1980 and 1981-82.

Even if tax and spending programs are unchanged, the projections are not likely to materialize because they are tethered to the CBO's forecasts of major macroeconomic variables. The $\mathrm{CBO}$ reportedly does not base its economic forecast on a single model, but rather uses a series of models, ad hoc judgments, and input from private sector forecasters and economists. ${ }^{20}$ For near-term budget projections, the $\mathrm{CBO}$ makes forecasts of the growth rate of real GDP, consumer price index (CPI) inflation, the unemployment rate, and the 3-month and 10-year Treasury rates. For longer-term projections (five years or more), however, the economy's underlying growth rate (which is largely determined by growth of labor productivity and population growth) plays the dominant role. These forecasts are referred to as economic assumptions. According$1 y$, budget projection errors that arise because of erroneous economic forecasts are referred to as economic assumption errors. The magnitude of these errors depends on the sensitivity of the budget projections to these economic assumptions and whether assumption errors for different macroeconomic variables offset or reinforce each other.

Finally, even if there were no changes in spending and tax programs and the CBO's economic assumptions materialized exactly, projections could still be wrong because of technical errors. Government expenditures and tax revenues vary with their source. For example, tax revenue broadly depends on not only the growth rate of the economy but also the relative size of corporate profits, the growth rate of personal income, and the extent to which individuals turn paper profits into cash (capital gains), to mention but a few. Hence, the CBO makes forecasts not only of key macroeconomic variables but also of many variables upon which taxes and expenditures depend. Hence, even if the CBO's forecasts of key economic variables were 100 percent accurate, its budget projections could be in error because it got the details wrong. ${ }^{21}$

There were two important examples of this phenomenon in recent years. The first was the welfare reform legislation passed in 1996, which reduced spending on income security and food stamps. The second was the unexpected boom in equity prices which, in spite of the reductions in long-term capital gains taxes in 1998 , led to a surge of individual income tax revenues. ${ }^{22}$

Another "detail" that may have contributed to a one-time projection error was the change in the construction of the CPI beginning in 1995. By 1999, the methodological changes in the construction of the CPI reduced the annual inflation rate by about 0.6 percentage points compared with the methodology employed to calculate the 1994 inflation rate. According to the CBO's analysis published in 1997, a reduction of 1 percentage point per year in the growth of the CPI would reduce the deficit by $\$ 653$ billion over the 1998-2007 projection period.

Overall, because many of these components, such as capital gains taxes, are notoriously difficult to forecast, one would not be surprised to find that technical errors account for a large proportion of the projection errors. Of course, economic assumption errors and technical errors need not be independent. For example, if economic growth is stronger than anticipated, corporate profits or capital gains may be stronger than anticipated as well.

\footnotetext{
${ }^{20}$ See CBO (1998).

${ }^{21}$ Note that these are all economic variables and, to that extent, the distinction between technical errors and economic assumption errors is somewhat blurred. See Altig (2000) for a discussion of this point.

22 Regarding the latter, see Kasten, Weiner, and Woodward (1999). The increased revenue from the surge in capital gains might be less important than the resulting change in the distribution of incomethat is, if proportionately more people are shifted into a higher (marginal) tax bracket.
} 


\section{Table 4}

Decomposition of CBO Deficit/Surplus Projection Errors: Five Years Ahead (Billions of Dollars)

Forecast error due to:

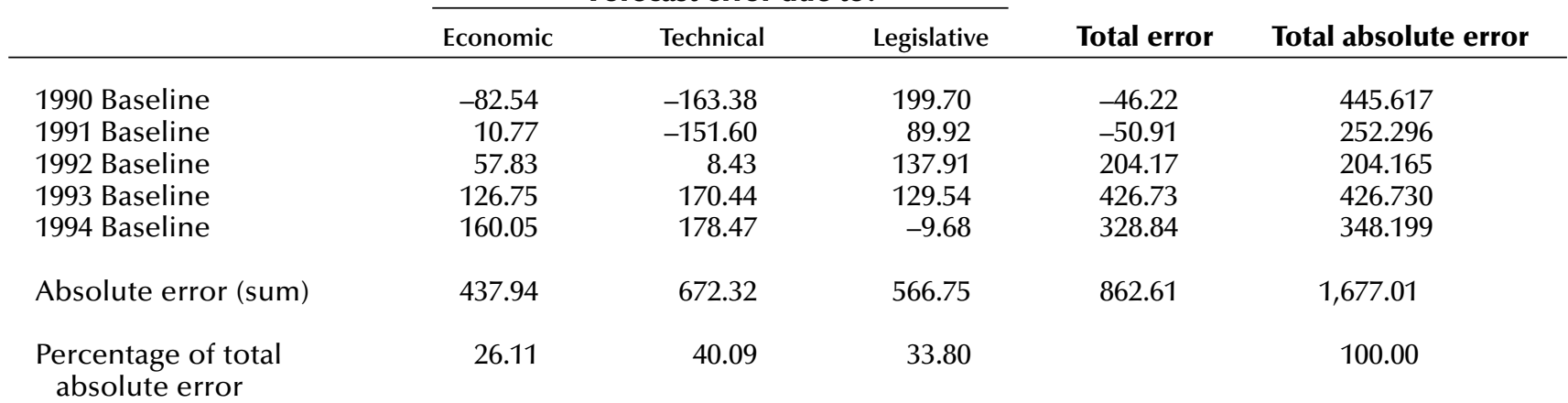

SOURCE: Congressional Budget Office, unpublished data.

\section{The Relative Importance of Legislative, Economic, and Technical Errors}

The CBO's analysis of the relative magnitude of legislative, economic, and technical errors is presented in Table 4. The CBO estimated that legislative errors account for about 35 percent of the average absolute projection error at the five-year horizon. They estimated that technical errors are the largest, accounting for over 40 percent of the average absolute projection error. Errors in forecasting the general economic outlook were the smallest at the five-year horizon, accounting for about 25 percent of the total projection error. Altig (2000) notes, however, that there is a close correspondence between technical errors and economic assumption errors because the former are the details related to the latter.

Projection errors arising from economic forecast errors have been relatively large in recent years. In 1999 and 2000, the CBO estimates that economic assumption errors accounted for 41 percent and 57 percent of the total absolute change in the projected 10-year surplus in 1999 and 2000, respectively.

\section{What Caused the Change in the Budget Outlook?}

Projections of relatively large unified budget surpluses over the next decade would have been viewed as highly implausible as recently as five years ago. Indeed, projections of large and rising federal budget deficits were the norm as late as January 1997. Figure 6 shows CBO's 10-year surplus/deficit projections for each year from 1994 through 2000, along with the revenue and outlay projections over the same periods. It was not until the federal government experienced its first surplus in 1998 that the $\mathrm{CBO}$ began projecting a persistent surplus. Prior to 1998 , the CBO projected a persistent deficit. Not only did the projections shift from deficits to surpluses in 1998, but the slope of the projection line went from being negative to being positive (i.e., the $\mathrm{CBO}$ went from projecting larger deficits over time to projecting larger surpluses over time).

What accounts for this dramatic turnaround in the budget outlook? Some have suggested that the outlook changed because of the Omnibus Budget Reconciliation Act of 1993 (OBRA93). ${ }^{23}$ This legislation ostensibly provided for $\$ 433$ billion in deficit reduction over the five-year period spanning 199498. This was to be accomplished through a combination of tax increases, reductions in mandatory spending, and caps on discretionary spending. Altig (2000) argues that the improved budget outlook is not due to OBRA93 because similar legislation, the Omnibus Budget Reconciliation Act of 1990 (OBRA90), promised - but failed to deliver - a $\$ 482$ billion reduction in the baseline deficit during the 1991-95 period. Despite OBRA90, Altig (2000) notes that the deficit increased by $\$ 6$ billion relative to levels projected prior to the bill's passage.

There is little question, however, that the marked improvement in the economy's performance between 1996 and 2000 has been a decisive factor in explaining the dramatic improvement in the federal government's budget. ${ }^{24}$ Consider the analysis of the CBO's baseline projections between 1996 and 2000 for the period 2000-06 in Table 5. First, there was a

\footnotetext{
23 The 2000 Economic Report of the President makes this claim. See p. 52.

${ }^{24}$ Altig (2000) also stresses this argument.
} 


\section{Figure 6}

\section{Baseline 10-Year Budget Projections, 1994-2000}
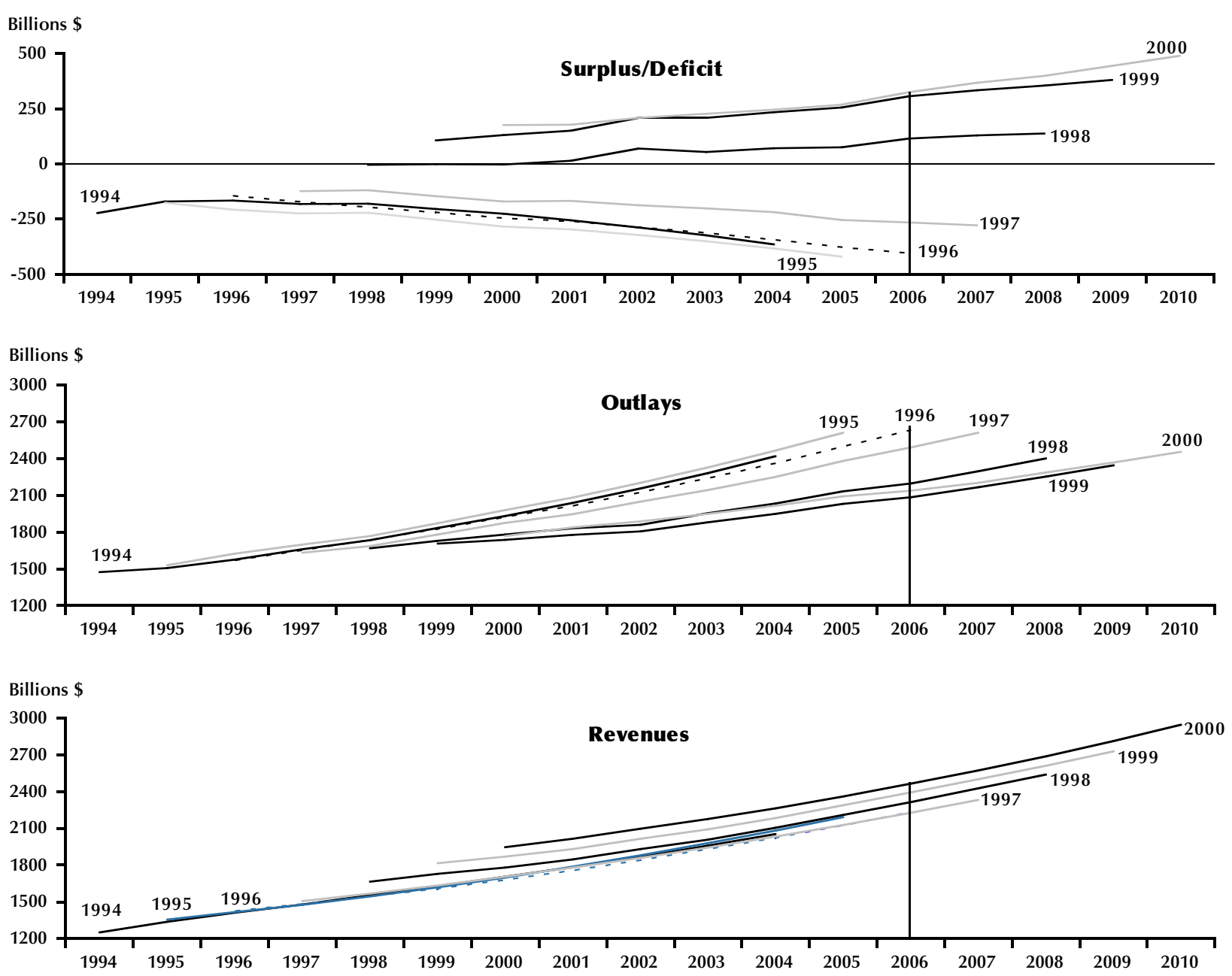

NOTE: Year indicates the CBO's first-of-the-year baseline budget forecast (typically published in January or February).

marked change in the economic assumptions used by the $\mathrm{CBO}$ in their projections between 1996 and 2000. As other private forecasters did, the CBO boosted its forecast of actual and potential GDP growth; it also scaled back its assumption for CPI inflation and for the unemployment rate.

Faster economic growth means larger tax revenues, whereas a lower unemployment rate leads to reductions in mandatory spending for unemployment compensation, welfare outlays, and the like. As line 3 in Table 5 shows, nearly all of the improvement in the outlook for revenues stemmed from a greater than expected surge in individual income taxes - the area where the CBO's revenue projections have been the least accurate at the five-year horizon.
Moreover, individual income tax revenue is projected to be higher by 1.2 percent of GDP in the 2000 projections compared with the 1996 projections.

On the outlay side, most of the improvement comes in mandatory expenditures, which are projected to be 2.3 percent lower as a percentage of GDP in 2000 compared with 1996 . The other major improvement on the outlay side is net interest. This reflects the reductions in inflation (which, all else equal, reduces nominal interest rates) and the reduction in the public's holding of government debt that have already occurred and are projected to occur. Perhaps more important, the evidence in Table 5 suggests that the improved economic outlook may be largely responsible for the improved long-term outlook as well. 


\section{Table 5}

Regime Shift? Change in Baseline Budget Projections and Economic Assumptions: 1996 vs. 2000 (Percent of GDP)

\begin{tabular}{ccccccc}
\multicolumn{4}{c}{ Tax revenues } & & \multicolumn{2}{c}{ Outlays } \\
\cline { 1 - 1 } $\begin{array}{c}\text { Individual } \\
\text { income }\end{array}$ & $\begin{array}{c}\text { Corporate } \\
\text { income }\end{array}$ & $\begin{array}{c}\text { Social } \\
\text { insurance }\end{array}$ & $\begin{array}{c}\text { Total tax } \\
\text { revenues }\end{array}$ & & Discretionary Mandatory Net interest & $\begin{array}{c}\text { Total } \\
\text { outlays }\end{array}$
\end{tabular}

\begin{tabular}{|c|c|c|c|c|c|c|c|c|}
\hline \multicolumn{9}{|c|}{ Change in budget assumptions } \\
\hline $\begin{array}{l}1996 \text { Baseline projection, } \\
1996-99 \text { average }\end{array}$ & 8.5 & 2.2 & 6.7 & 18.9 & 6.8 & 12.1 & 3.1 & 21.1 \\
\hline $\begin{array}{l}\text { Actual outcome, } \\
\text { 1996-99 average }\end{array}$ & 9.2 & 2.2 & 6.6 & 19.5 & 6.6 & 10.9 & 2.9 & 19.4 \\
\hline Projection error & -0.7 & 0.0 & 0.1 & -0.6 & 0.2 & 1.2 & 0.2 & 1.7 \\
\hline $\begin{array}{l}1996 \text { Baseline projection, } \\
2000-06 \text { average }\end{array}$ & 8.6 & 1.8 & 6.7 & 18.5 & 6.1 & 13.1 & 3.1 & 21.5 \\
\hline $\begin{array}{l}2000 \text { Baseline projection, } \\
2000-06 \text { average }\end{array}$ & 9.8 & 1.8 & 6.8 & 20.0 & 6.1 & 10.8 & 1.8 & 17.9 \\
\hline Difference: 1996 vs. 2000 & 1.2 & 0.0 & 0.1 & 1.5 & 0.0 & -2.3 & -1.3 & -3.6 \\
\hline \multicolumn{9}{|l|}{ Memorandum (1970-95) } \\
\hline Average & 8.2 & 2.1 & 5.9 & 18.0 & 9.7 & 10.4 & 2.3 & 21.2 \\
\hline High & $9.3(1981)$ & $3.2(1970)$ & 6.7 (1991) & 19.6 (1981) & $11.9(1970)$ & 11.9 (1983) & 3.3 (1991) & 23.5 \\
\hline Low & $7.6(1976)$ & $1.1(1983)$ & $4.4(1970)$ & 17.2 (1976) & 7.5 (1995) & 7.1 (1970) & 1.3 (1973) & 18.7 (1974) \\
\hline
\end{tabular}

\begin{tabular}{lcccc} 
& $\begin{array}{c}\text { Growth of } \\
\text { real GDP }\end{array}$ & $\begin{array}{c}\text { Growth of } \\
\text { potential } \\
\text { GDP }\end{array}$ & $\begin{array}{c}\text { CPI } \\
\text { inflation }\end{array}$ & $\begin{array}{l}\text { Unemployment } \\
\text { rate }\end{array}$ \\
\hline Change in economic assumptions & & & & \\
Date of baseline projections & & & & \\
May 1996 (1996 to 2006) & 2.1 & 2.2 & 3.0 & 4.0 \\
January 2000 (1999 to 2010) & 2.9 & 3.1 & 2.5 & \\
NOTE: Averages of fiscal years indicated. & & & & \\
\hline
\end{tabular}

\section{CONCLUSION}

Projecting the path of federal government receipts and expenditures-and thus the unified budget surplus or deficit-several years into the future is a daunting task. This is why the CBO cautions users on the highly uncertain nature of their long-term budget projections. Moreover, budget projections provide a method of analyzing alternative budget proposals: they are not intended to be used as forecasts. Nevertheless, policymakers and the public often treat them as such. Indeed, there are many proposals to cut taxes or increase spending based on these projections. Our analysis of the CBO's record of projecting budget surpluses and deficits at the five-year horizon suggests that the public and policymakers should be wary of changing spending and tax programs based on projections of the surplus or deficit. Specifically, there is no statistically significant relationship between projections and experience. There is no reason to suspect that things are different now.
In addition, past projections were biased in the direction of under-projecting the size of the deficit. Moreover, the size of the bias is very large - nearly 2 percent of GDP. If the current projections are biased to a similar degree and policymakers choose to alter current tax and spending programs based on these projections, it is possible that the projected surpluses will never materialize.

Even if historical regularities fail to hold and legislators decide to forgo sizable future income tax reductions and expenditure increases, the budget surpluses that are currently projected to prevail over the medium term are likely to evaporate over the long term because of the retirement of the baby boom generation. The trust fund surpluses, which account for the bulk of the current projected unified budget surpluses, will not be available after about 2015. When this happens, the government will have to resume borrowing from the public, unless there are surpluses in other areas of the government. Given this reality and the likelihood that actual 
surpluses will be much smaller than projected, we believe that the concern expressed in some quarters-that there will not be a market for risk-free government debt-is significantly overstated. Even if the budget projections were reasonably accurate, the demise of this market likely would be only temporary.

\section{REFERENCES}

Altig, David. "Fiscal Policy and Fickle Fortunes: What's Luck Got to Do With It?" Federal Reserve Bank of Cleveland, Economic Commentary, 1 April 2000.

Auerbach, Alan J. "Formation of Fiscal Policy: The Experience of the Past Twenty-Five Years," in Fiscal Policy in an Era of Surpluses: Economic and Financial Implications. Proceedings of a Conference sponsored by the Federal Reserve Bank of New York, April 2000, pp. 9-23.

"On the Performance and Use of Government Revenue Forecasts." National Tax Journal, December 1999, 52(4), pp. 767-82.

Board of Governors of the Federal Reserve System. "Minutes of the Federal Open Market Committee Meeting, March 21, 2000.” Press Release, 18 May 2000.

Cecchetti, Stephen G. "The Disappearance of U.S. Treasury Securities: Should We Care?" Occasional Essays on Current Policy Issues No. 7, 3 May 2000,

$<$ http://www.econ.ohiostate.edu/cecchetti/pdf/cpi7.pdf > .

Congress of the United States. The Budget and Economic Outlook: Fiscal Years 2001-2010. A Report to the Senate and House Committees on the Budget. Washington, DC: Congressional Budget Office, January 2000a.

The Budget and Economic Outlook: An Update. A Report to the Senate and House Committees on the Budget. Washington, DC: Congressional Budget Office, July 2000b.

The Long-Term Budget Outlook. Washington, DC: Congressional Budget Office, October 2000c.

Description of Economic Models. CBO Paper. Washington, DC: Congressional Budget Office, November 1998.

Council of Economic Advisers. Economic Report of the President. Washington, DC: U.S. Government Printing Office, February 2000
Dupont, Dominique and Sack, Brian. "The Treasury Securities Market: Overview and Recent Developments." Federal Reserve Bulletin, December 1999, pp. 785-806.

Federal Reserve Bank of New York. Fiscal Policy in an Era of Surpluses: Economic and Financial Implications. Proceedings of a Conference sponsored by the Federal Reserve Bank of New York, April 2000.

Frum, David. “The Amazing Vanishing Surplus.” New York Times, 7 July 1999.

Gokhale, Jagadeesh; Page, Benjamin R.; Potter, Joan and Sturrock, John R. "Generational Accounts for the United States: An Update." The American Economic Review, Papers and Proceedings, May 2000, 90(2), pp. 293-96.

Harris, John F. and Pianin, Eric. "Surplus Estimate is Doubled.” Washington Post, 26 June 2000.

Kasten, Richard A.; Weiner, David J. and Woodward, G. Thomas. "What Made Receipts Boom and When Will They Go Bust?" National Tax Journal, September 1999, 52(3), pp. 339-47.

Meulendyke, Ann-Marie. U.S. Monetary Policy \& Financial Markets. Federal Reserve Bank of New York, 1998.

Meyer, Laurence H. "How Does a Surplus Affect the Formulation and Conduct of Monetary Policy?" Remarks before the 16th Annual Policy Conference of the National Association for Business Economics. Washington, DC: 23 February 2000.

National Association for Business Economics. "NABE Economic Policy Survey.” NABE News, March/April 2000, pp. 8-9.

Office of Management and Budget. Mid-Session Review. Budget of the United States Government, Fiscal Year 2001. Washington, DC: U.S. Government Printing Office, 26 June 2000.

Rasche, Robert H. "Deficit Projections vs. Deficit Forecasts.” Federal Reserve Bank of San Francisco Weekly Letter, 5 July 1985.

"Financing the Government Deficit," in Warren J. Samuels and Larry L. Wade, eds., Taxing and Spending Policy. Lexington Books, 1980, pp. 77-83.

Reifschneider, David; Tetlow, Robert and Williams, John. "Aggregate Disturbances, Monetary Policy and the 
Macroeconomy: The FRB/US Perspective.” Federal

Reserve Bulletin, January 1999, pp. 1-19.

Reischauer, Robert. “The Phantom Surplus.” New York Times, 28 January 2000.

Stevenson, Richard W. "A Debate Over Dividing Tax Dollars Yet to Be Collected.” New York Times, 10 August 1999.
Treasury News. "Undersecretary of the Treasury for Domestic Finance Gary Gensler Remarks at the May 2000 Treasury Quarterly Refunding." Washington, DC: Office of Public Affairs, 3 May 2000.

Weill, Sanford I. "Report to the Business Council on Economic Issues.” Business Council Press Release, 10 May 2000.

\section{Appendix}

On January 31, 2001, the Congressional Budget Office released its baseline budget projections for fiscal years 2002 to $2011 .{ }^{1}$ Consistent with the theme of recent reports, the Agency once again revised upward its projected cumulative budget surplus during the coming decade. According to the new projections, unified budget surpluses for the fiscal years 2002 to 2011 are expected to total just over \$5.6 trillion. The outgoing Clinton Administration's final baseline (current services) projection is slightly less optimistic, but not by much, totaling roughly $\$ 5$ trillion. These figures are substantially larger than a year earlier, when the $\mathrm{CBO}$ was projecting a cumulative $\$ 3.2$ trillion surplus and the OMB (baseline) was projecting a $\$ 2.5$ trillion surplus, and modestly greater than last year's mid-year estimates (see Table 1, page 12).

In part, the larger surpluses reflect the addition of an extra "out year" (2011) that is considerably larger than the surplus for the year that was dropped (2001). For example, the CBO's projected surplus for 2011, $\$ 889$ billion, is $\$ 608$ billion more than the projected 2001 surplus. The factor that is most responsible for the upward revision, however, is a more optimistic assessment of the economy's potential output growth. Both the $\mathrm{CBO}$ and the OMB now project that real GDP growth will average slightly more than 3 percent during the next 10 years, roughly a quarter of a percentage point more than last year's average projected growth. Faster economic growth, accordingly, is expected to boost projected revenues significantly. Comparing this year's 10-year projections for fiscal years 2001 to 2010 with last year's, the CBO estimates that cumulative revenues will be nearly 9 percent larger, while outlays are only expected to be 1.5 percent higher.

Since this article was prepared, the economy slowed appreciably during the second half of 2000 , and most forecasters - including the $\mathrm{CBO}-$ expected its growth in 2001 to be about a percentage point below its potential growth. Since most forecasters assume the economy will bounce back quickly to a rate near or slightly above its trend growth, the effect on the cumulative surplus is expected to be minor. Moreover, the $\mathrm{CBO}$ ran an alternative simulation which assumes a recession in 2001 of approximately the same magnitude as the 1990-91 recession. In that scenario, the cumulative surplus for the period 2002 to 2011 is cut from $\$ 5.61$ trillion to $\$ 5.48$ trillion.

A more important development, which is in part a consequence of the projected surpluses, is the likelihood of expansionary fiscal policy. In early February 2001, the Bush Administration announced that it was sending to Congress a proposal that, among other items, reduces marginal tax rates, doubles the child tax credit, and reduces the marriage penalty. Though specifics of the proposal were not available as this article went to press, commentary from Administration officials suggests the total reduction in tax revenues would amount to $\$ 1.6$ trillion over a 10-year horizon (the timing of the tax cuts was yet to be decided).

Generally speaking, an expansionary fiscal policy reduces tax revenues. The Bush package, however, includes reductions in marginal tax rates, which could enhance the economy's growth potential by increasing the incentives to save and invest - thereby boosting capital formation and productivity growth. Consequently, should it be adopted, the ultimate effect of the President's package on the budget is difficult to predict.

\footnotetext{
1 Congress of the United States. The Budget and Economic Outlook: Fiscal Years 2002-2011. A Report to the Senate and House Committees on the Budget. Washington, DC: Congressional Budget Office, January 2001
} 